Simplified Mandelic Acid Treatment of Urinary Infections

THE use of mandelic acid, a new urinary antiseptic, was the subject of a note in a former issue of NATURE $(136,482 ; 1935)$. In order that the antiseptic action may be exerted, it is necessary for the urine to be acid $(p H$ below $\mathbf{5 \cdot 5}$ ), and this was at first effected by the simultaneous administration of ammonium chloride in an amount of 4-8 gm. daily. Treatment with this agent has now been simplified in various ways, which also tend to reduce the disadvantages of the original method, such as the risk of nausea and vomiting, excessive acidity, and albuminuria with casts. Boots Pure Drug Co., Ltd., Station Road, Nottingham, compound the mandelic acid with acid sodium phosphate as the acidifying agent, with sodium bicarbonate in sufficient quantity to neutralise the acid, and suitably sweetened with saccharin. This preparation is put up under the name of 'Neoket', compound mandelic acid granules, the dose of which is two teaspoonfuls in a little water four times a day. The British Drug Houses, Ltd., Graham Street, London, N.1, make use of ammonium mandelate, which is put in the form of an elixir under the name of 'Mandelix', of which 2 fluid drachms constitutes the normal adult dose. This usually suffices to maintain the requisite acidity; exceptionally, it may be necessary to administer ammonium chloride in addition, for which purpose capsules containing gramdoses are supplied. A 'Mandelix Outfit' contains these agents, together with a testing outfit to ensure the proper urinary acidity. Descriptive booklets may be obtained on application from the two firms named.

\section{Mining in South Australia}

Ww have received from the Department of Mines, South Australia, the "Mining Review", No. 62, for the half year ending June 30, 1935. After some preliminary notes on recent mining legislation, including where and how to get more details for those who require them, there follows a series of reports on Government drilling and Government gold and silver recovery, reports of the Commonwealth Council of Scientific and Industrial Research, reports by the Government assistant geologist and various inspectors of mines, etc. The total value of the mineral production of the State of South Australia from 1841 until 1934 is given as $53 \frac{1}{4}$ million sterling, of which copper ranks for something more than 33 millions, ironstone for $12,200,000$ and gold only for $1 \frac{3}{4}$ millions, the production of the other minerals being unimportant.

\section{Czechoslovak Microchemical Society}

A CzechoslovaK Microchemical Society was founded on April 25 in Prague at a gathering of about two hundred chemists, from both Czech and German scientific and industrial circles. Prof. J. Heyrovský, professor of physical chemistry at the Charles University, known for his microchemical polarographic studies, has been elected president. The Society's activities were inaugurated by a lecture by Dr. C. J. van Nieuwenburg, professor of analytical chemistry in the Delft Technical High School, on
"Why and Where Microchemistry?" Austrian microchemists were represented by Prof. Fritz Feigl, professor of chemistry in the University of Vienna. The Society intends to co-operate with microchemical societies and clubs of England, America, Holland and Austria with the view of establishing an International Microchemical Society. The official title of the Society is "Societas microchemica C.S.R." and its address Prague II, Albertov 2030.

\section{Eugenics Research}

LAST year, a Darwin Research Studentship, tenable for two years, was established by the Eugenics Society in honour of Major Leonard Darwin, the award being made to Dr. R. B. Cattell, director of the School Psychological Clinic of Leicester. Dr. Cattell has been investigating the application of intelligence tests to (a) a typical urban, $(b)$ a typical rural population of school children, to determine the average size of family at each level of intelligence. $\mathrm{He}$ is also applying intelligence tests to adults and children in the same families, to determine the correlation rates between parents and offspring. A second Darwin Research Studentship has now been established by the Eugenics Society on the same terms, for the investigation of racial crossing. The holder of this Studentship, which is of the value of $£ 250$ a year, will begin work in October. The particular aspects of racial erossing to be investigated will be determined after applications have been received.

\section{The 200-in. Telescope Disk}

THE successful casting of the 200-in. telescope disk at the Corning Glass Works, America, has aroused world-wide interest during the past eighteen months. An opportunity is being given to English scientific workers to learn some of the details of this achievement since Dr. J. C. Hostetter, director of development research at the Corning Glass Works, who has been intimately associated with the casting of the disk, is to give an address on the subject on Friday afternoon, July 3, at 4.30 p.m. in the lecture theatre of the Institution of Electrical Engineers, Savoy Place, London. The lecture has been arranged under the auspices of the International Congress on Glass which opens in London on July 2, and Sir William Bragg has kindly consented to take the chair at the lecture. Admission is free and no tickets are required. Further information, however, may be obtained from Prof. W. E. S. Turner, General Organising Secretary, International Congress on Glass, University, Darnall Road, Sheffield, 9.

\section{Royal Geographical Society: Medals and Grants}

His MaJesty THe KING has approved the following awards of the Royal Medals of the Royal Geographical Society : Founder's Medal to Mr. G. W. Murray, director of desert surveys, Egypt, for his long-continued explorations and surveys in the deserts of Sinai and eastern Egypt; for his studies of Badawin tribes, and his unstinted help to desert expeditions; Patron's Medal to Major R. E. Cheesman, for valuable 